(C) 2017 Wiley. This is the author's version of the following article:

Stewart Clem, "The Passions of Christ in the Moral Theology of Thomas Aquinas: An Integrative Account," New Blackfriars (2017) (in press DOI: http://dx.doi.org/10.1111/nbfr.12286)

which will be published in final form at http://dx.doi.org/10.1111/nbfr.12286. This article may be used for noncommercial purposes in accordance with Wiley Terms and Conditions for Self-Archiving. Please consult the published version before citing or quoting.

Author's contact information: Stewart Clem, Department of Theology, University of Notre Dame, 130 Malloy Hall, Notre Dame, IN 46556, USA, sclem@nd.edu

\title{
The Passions of Christ in the Moral Theology of Thomas Aquinas: An Integrative Account
}

\section{Stewart Clem}

\begin{abstract}
In recent scholarship, moral theologians and readers of Thomas Aquinas have shown increasing sensitivity to the role of the passions in the moral life. Yet these accounts have paid inadequate attention to Thomas's writings on Christ's passions as a source of moral reflection. As I argue in this essay, Thomas's writings on Christ's human affectivity should not be limited to the concerns of Christology; rather, they should be integrated into a fuller account of the human passions. One upshot of this approach for Thomists is that it sharpens our vocabulary when describing human nature and the conditions for the moral life. By considering the rubrics of creation, fall, and redemption - as Thomas does - we find that our resources for analyzing the passions are greatly enriched.
\end{abstract}

\section{Keywords}

Aquinas, Christology, passions, anthropology, moral theology

\section{Introduction}

Thomas Aquinas's account of the passions has enjoyed a resurgence in recent scholarship, but surprisingly little attention has been given to the ways in which this account might intersect with other areas of his thought. This essay examines Thomas's theology of Christ's passions in 
Question 15 of the Tertia Pars of the Summa Theologiae ${ }^{1}$ in comparison with his treatment of Adam's nature in the state of innocence in Question 95 of the Prima Pars. I argue that Thomas's account of the passions (and by implication, his theological anthropology on the whole) cannot be understood apart from the economy of salvation. That is, since Christ's human affectivity illustrates most perfectly the proper relationship between the passions and the higher aspects of the soul, the Christological concerns in STh III, q. 15 are not simply an application of Thomas's theory of the passions to the case of Christ, but rather they present the culmination of Thomas's analysis of human passions and therefore should be considered a central text not only in Thomas's Christology, but in his anthropology and moral theology.

It is by comparing the passions of the soul in the 'First Adam' and 'Second Adam' (1 Cor. 15:45) that we see most clearly how Christ is the exemplar of virtue and the eschatological image of the viator et comprehensor. Christ's humanity was a true humanity; it was not humanity in the precise mode as that of our first parents, nor in that of ourselves in the present state, but it was the fullness of humanity. In his treatment of Christ's assumed defects, for example, many of Thomas's arguments and responses to objections rely on the premise that Christ must have been entirely without $\sin$ in order for to effect our salvation. His analysis of Christ's animal passions reveals that, far more than just providing a defense of Christ's sinlessness, Christ's humanity provides the perfect icon of moral perfection and holiness.

Christ's humanity and, by extension, his passions were different from Adam's, and this is because the humanity that needed to be redeemed was in a different state than Adam's, and therefore Christ took on certain defects that did not belong to Adam. Yet, Christ's humanity was different from ours because, in order for his Incarnation to be salvific, his humanity must have

\footnotetext{
${ }^{1}$ Citations of the Summa in this essay are taken from Thomas Aquinas, Summa Theologiae, 8 Vols (Latin and English), ed. John Mortensen and Enrique Alarcón (Lander, WY: The Aquinas Institute for the Study of Sacred Doctrine, 2012).
} 
been devoid of certain defects that were opposed to the perfection of virtue. This is the guiding principle for determining which defects Christ's humanity did or did not have: those ordered toward the salvation of the human race were assumed by Christ; those that were not ordered to this end (or opposed to it) were not assumed. Moreover, there are even stronger implications beyond the claim that Christ's humanity was a true humanity or the claim that his humanity was instrumental in our salvation. Thomas is concerned to make the point that, given what we can learn about the passions of Christ's soul, we can better follow and conform to him as the exemplar of virtue, and, furthermore, we acquire a deeper understanding of the end of virtue as it leads to beatitude.

\section{Thomas's Account of the Passions}

It is worth mentioning from the outset that Thomas's Treatise on the Passions (STh I-II, qq. 2248 ) is longer than any other treatise within the Summa Theologiae. ${ }^{2}$ It contains more questions (and more text overall) than any of his better-known treatises on the Trinity, grace, habits, and law. Furthermore, it represents the most extensive treatment of the topic during the medieval era. Until relatively recently, philosophers and theologians have for the most part neglected this area of Thomas's thought. As interest in the topic has revived, scholars have begun to appreciate the

\footnotetext{
${ }^{2}$ My overview of Thomas on the passions relies primarily on his mature teaching found in the Summa. While Thomas does treat the passions in De Veritate and other works, he is much less systematic in those instances. Mark Jordan offers an insightful analysis of the structure and genre of Thomas's account of the passions (primarily as found in the Sentences commentary, the Summa, and De Veritate) in his essay "Aquinas's Construction of a Moral Account of the Passions," in Freiburger Zeitschrift für Philosophie und Theologie, Vol. 33 (1986): 71-97. While I disagree with Jordan's claim that for Thomas the moral life is wholly contemplative, I agree with his assessment, "Indeed, it may be that the shape of the Summa's treatment of moral matters is the most eloquent - and the most pointed - argument for the teleology that makes possible a reasonable control over the passions" (97).
} 
importance of this topic not only as it relates to the rest of Thomas's thought, but also as a significant contribution to contemporary debates surrounding the psychology of the emotions. ${ }^{3}$

For Thomas, a passion is simply a movement of the sensitive appetite. ${ }^{4}$ Although passions are movements of the soul (insofar as they involve conscious perception), they also involve some kind of bodily modification. ${ }^{5}$ In and of themselves, passions are morally neutral; they are always inclined toward or away from some particular, immediate thing, and the object of the inclination is the measure of the passion's moral value. ${ }^{6}$ In Augustine's words, “They are evil if our love is evil; good if our love is good." ${ }^{, 7}$ Because they originate in the sensitive appetite, they are counted among the "pre-rational" aspects of human nature, and, indeed, they represent a shared feature of all animal life. The important difference, according to Thomas, is that human

\footnotetext{
${ }^{3}$ Three important monographs on Aquinas's account of the passions have been released within the last few years, roughly around the same time. As a result, none of these authors interacts with the others, and there is quite a bit of overlap among the three books. Each has a particular angle and focus, however. Diana Fritz Cates, Aquinas on the Emotions: A Religious-Ethical Inquiry (Washington, DC: Georgetown University Press, 2009) is especially interested in Thomas's account with an eye toward contemporary concerns and as a contribution toward constructing a general account of the emotions. Nicholas E. Lombardo, O.P., The Logic of Desire: Aquinas on Emotion (Washington, DC: Catholic University of America Press, 2011) writes his analysis in conversation with contemporary analytic philosophy, and his text is unique in that it contains an entire chapter on the passions of Christ's soul (which draws heavily from Gondreau; see below). Robert Miner, Thomas Aquinas on the Passions: A Study of Summa Theologiae, la2ae 22-48 (Cambridge: Cambridge University Press, 2009) is the most straightforwardly exegetical; it is narrowly focused on the treatise on the passions in the Summa, but it is quite thorough and contains helpful tables and figures that illuminate complex aspects of Thomas's account. ${ }^{4}$ In STh I-II, q. 22, a. 3 sc, Thomas affirms the definition given by John of Damascus: "Sed contra est quod dicit Damascenus, in II libro, describens animales passiones, passio est motus appetitivae virtutis sensibilis in imaginatione boni vel mali. Et aliter, passio est motus irrationalis animae per suspicionem boni vel mali." Miner observes that Thomas could have easily given an Aristotelian definition, but chose not to. He suggests that Thomas intentionally chose the Damascene's incomplete definition for pedagogical reasons: "Rather than provide a complete definition of passion at the beginning, Aquinas employs a more subtle strategy. He desires that the reader should sift through the proposals of a range of auctoritates - Aristotle, Cicero, Damascene, Nemesius, and Augustine among them - so that she might arrive at a conception that includes elements of the integral tradition," Thomas Aquinas on the Passions, 31.

${ }^{5}$ STh I-II, q. 22, a. 3: "[P] assio proprie invenitur ubi est transmutation corporalis."

${ }^{6}$ STh I-II, q. 24, a. 4 ad 2: "[P] assiones quae in bonum tendunt, si sit verum bonum, sunt bonae, et similiter quae a vero malo recedunt. E converso vero passiones quae sunt per recessum a bono, et per accessum ad malum, sunt malae."

${ }^{7}$ Thomas cites this statement (from De Civ. Dei xiv, 7) in STh I-II, q. 24, a. 1 sc.
} 
passions are (or at least can be) subject to the command of will and reason. ${ }^{8}$ As Kevin White observes, "With likeness to both, passions are motions situated 'between' spiritual and bodily motions." 9 Thus, the passions stand at the crux of Thomas's anthropology, and they underscore the Aristotelian notion that the human being is a rational animal. ${ }^{10}$

Thomas's structure of the Treatise on the Passions roughly follows the division of the sensitive soul into the concupiscible and irascible appetites. He explains this basic twofold division thusly,

[T] he object of the concupiscible power is sensible good or evil, simply apprehended as such, which causes pleasure [delectabile] or pain [dolorosum]. But, since the soul must, of necessity, experience difficulty or struggle at times, in acquiring some such good, or in avoiding some such evil, insofar as such good or evil is more than our animal nature can easily acquire or avoid; therefore this very good or evil, inasmuch as it is of an arduous or difficult nature, is the object of the irascible faculty. ${ }^{11}$

The result of this division is that certain passions pertain to good or bad absolutely and immediately (joy, sorrow, love, hatred, etc.), and these belong to the concupiscible appetite; other passions pertain to good or bad through difficulty (daring, fear, hope, etc.), and these belong to the irascible appetite. ${ }^{12}$ The passions can also be grouped as pairs of contraries. The first type of contrary regards the goodness or badness of the objects to which the passions are responding. Thus, in the concupiscible appetite, the passions of love, desire, and joy incline toward the good, whereas the passions of hatred, aversion, and sorrow tend away from evil; in

\footnotetext{
${ }^{8}$ STh I-II, q. 24, a. 1: "Dicuntur autem voluntariae vel ex eo quod a voluntate imperantur, vel ex eo quod a voluntate non prohibentur." STh I-II, q. 24, a. 1 ad 1: "[I]stae passiones secundum se consideratae, sunt communes hominibus et aliis animalibus, sed secundum quod a ratione imperantur, sunt propriae hominum."

${ }^{9}$ Kevin White, "The Passions of the Soul (Ia IIae, qq. 22-48)," in The Ethics of Aquinas, Ed. Stephen J. Pope (Washington, DC: Georgetown University Press, 2002), 103. White's article offers perhaps the best brief overview of Thomas's account of the passions. It is especially good in highlighting Thomas's use of metaphorical language to describe the passions as movements of sensitive appetite.

${ }^{10}$ STh I, q. 79, a. 8 ad 3. For an insightful essay on the ways in which Thomas's account of the passions provides a remedy to the problems inherent in contemporary debates about human nature, see Reinhard Hütter, "Body Politics beyond Angelism and Animalism: The Human Passions and Their Irreducible Spiritual Dimension," in Dust Bound for Heaven: Explorations in the Theology of Thomas Aquinas (Grand Rapids, MI: Eerdmans, 2012), 75-101.

${ }^{11}$ STh I-II, q. 23, a. 1.

${ }^{12}$ Ibid.
} 
the irascible appetite, the passions of hope and daring incline toward the good, whereas the passions of despair and fear tend away from evil. ${ }^{13}$ Due to the nature of the irascible appetite, the passions that belong to it may also be classified in a second type of contrary: approach and withdrawal in respect to the same object. As Thomas explains, "[T]he object of the irascible faculty is sensible good or evil, considered not absolutely, but under the aspect of difficulty or arduousness." ${ }^{\prime 14}$ So, for example, if a person is motivated to pursue an object through hope (imagine, for example, a man stranded in the desert who sees a body of water in the distance), it is possible that same object, if it is perceived as too difficult to obtain, will then become a source of despair. ${ }^{15}$ Thus, the divisions of the concupiscible and irascible appetites, as well as the theoretical divisions of contraries, set the basic framework for Thomas's structuring of the passions.

The result of this framework is a definitive classification of eleven passions. These include love (amor), hatred (odium), desire (desiderium or concupiscentia), aversion (fuga or abominatio), joy (gaudium or delectatio), sadness (dolor or tristitia) hope (spes), despair (desperatio), fear (timor), daring (audacia), and anger (ira). ${ }^{16}$ This list reflects Thomas's mature teaching on the passions, and it also unique to him among the various scholastic classifications. ${ }^{17}$ Furthermore, just as the virtues are reducible to four cardinal virtues, ${ }^{18}$ Thomas holds that these

\footnotetext{
${ }^{13}$ STh I-II, q. 23, a. 2. The passion of anger does not fall within this schema since it does not have a contrary (STh III, q. 23, a. 3: "Unde motus irae non potest habere aliquem motum animae contrarium, sed solummodo opponitur ei cessatio a motu, sicut philosophus dicit, in sua rhetorica, quod mitescere opponitur ei quod est irasci, quod non est oppositum contrarie, sed negative vel privative."). Moreover, anger finds its source in the passion of daring (STh III, q. 25, a. 4 ad 3).

${ }_{15}^{14}$ STh I-II, q. 23, a. 2.

${ }^{15}$ Miner provides a helpful and very thorough analysis of the movements of the passions in Ch. 3, "The activation of passion," in Thomas Aquinas on the Passions, 58-87.

${ }^{16}$ STh I-II, q. 23, a. 4.

${ }^{17}$ See Paul Gondreau, The Passions of Christ's Soul in the Theology of St. Thomas Aquinas (Chicago, IL: University of Scranton Press, 2009), 102-107.

${ }^{18}$ STh I-II, q. 61, a. 2
} 
eleven passions may be reduced to four "principle" passions: joy, sadness, hope, and fear. ${ }^{19}$ The logic behind this is that each of these somehow completes the other passions, either in relation to the present or in relation to the future. ${ }^{20}$ Thus, passions either find their ultimate rest in joy or sadness (in the present), or they culminate in a movement that is oriented toward hope or fear (in the future). For example, Thomas explains, “[I]n respect of good, movement begins in love, goes forward to desire, and ends in hope; while in respect of evil, it begins in hatred, goes on to aversion, and ends in fear." ${ }^{21}$ Simply stated, these principal passions most clearly reflect the tendency of the sensitive appetite, as a basic feature of our animal nature, to incline toward or away from some particular thing. ${ }^{22}$

Another vitally important feature of the passions is their inherent relation to moral development. ${ }^{23}$ For Thomas, the passions are the subjects of the moral virtues insofar as the virtues reflect a harmony of the passions in relation to reason and will. ${ }^{24}$ Unlike the Stoics, Thomas asserts that the right ordering of the passions - not their suppression or elimination - is constitutive of the moral life. ${ }^{25}$ While there are other important components of Thomas's moral

\footnotetext{
${ }^{19}$ STh I-II, q. 25, a. 4.

${ }^{20}$ Ibid.: "Et ideo solet harum quatuor passionum numerus accipi secundum differentiam praesentis et futuri, motus enim respicit futurum, sed quies est in aliquo praesenti. De bono igitur praesenti est gaudium; de malo praesenti est tristitia; de bono vero futuro est spes; de malo futuro est timor."

${ }^{21}$ Ibid.: "[R] espectu boni, incipit motus in amore, et procedit in desiderium, et terminatur in spe; respectu vero mali, incipit in odio, et procedit ad fugam, et terminatur in timore."

${ }^{22}$ Alexander Brungs aptly summarizes the logic behind the principal passions: "Das, was eine Regung des sinnengebundenen Strebevermögens also zu einer grundlegenden Regung macht, ist ihr in Relation zu den anderen Affekten zielhafter, vervollständigender, mithin abschließender Charakter," in Metaphysik der Sinnlichkeit: Das System der Passiones Animae bei Thomas von Aquin (Hallescher Verlag: Akademische Studien Vorträge, Nr. 6, 2002), 103.

${ }^{23}$ See Cates, Aquinas on the Emotions, 213-240; Paul Gondreau, "Passions and the Moral Life: Appreciating the Originality of Aquinas," in The Thomist 71 (2007): 419-50; Lombardo, The Logic of Desire, 148-200; Miner, Thomas Aquinas on the Passions, 88-108; and Servais Pinckaers, "Reappropriating Aquinas's Account of the Passions," in The Pinckaers Reader: Renewing Thomistic Moral Theology, ed. John Berkman and Craig Steven Titus (Washington, DC: Catholic University of America Press, 2005), 273-287.

${ }^{24}$ STh I-II, q. 56, a. 4.

${ }^{25}$ STh I-II, q. 59, a. 5: "[S]i passiones dicamus inordinatas affectiones, sicut Stoici posuerunt; sic manifestum est quod virtus perfecta est sine passionibus. Si vero passiones dicamus omnes motus appetitus sensitivi, sic planum est quod virtutes morales quae sunt circa passiones sicut circa propriam materiam, sine passionibus esse non possunt."
} 
theology - namely, the fruits, beatitudes, and gifts ${ }^{26}$ of the Holy Spirit, as well as the operation of grace, generally ${ }^{27}$ - the virtues and, by extension, the passions play a central role in his moral analysis. Thomas states that some passions are good or evil according to their species ${ }^{28}$ and, furthermore, that the irascible and concupiscible powers of the soul can be subjects of virtue, ${ }^{29}$ and a fortiori, that moral virtue cannot exist without the passions. ${ }^{30}$ In short, "The moral significance of all passions," as White explains, "is due to their capacity to attract, command, or absorb the soul's attention." 31 Growth in virtue involves the ordering of the passions such that the soul's attention is given over to that which is truly good.

Moreover, for the purposes of this paper, an important feature of Thomas's understanding of the nature of morality must be noted: for Thomas, morality is not merely concerned with "duty" or "obligation." The final end of morality is beatitude; thus, the passions participate in the human person's journey (i.e. as viator) toward beatitude. ${ }^{32}$ It should also be noted that Thomas's treatise on the passions is a meant to contribute, first and foremost, to a conception of human nature per se; he does not situate his discussion of the passions within any one specific state or condition in which humanity might find itself. Although he does include in the treatise those passions that were absent in the state of innocence, this suggests that his intention was to treat the

\footnotetext{
Brungs offers a helpful overview of Thomas's engagement with the Stoics' understanding of the passions in Metaphysik der Sinnlichkeit, 84-102.

${ }^{26}$ STh I-II, qq. 68, 69, and 70, respectively.

${ }^{27}$ STh I-II.109-114.

${ }^{28}$ STh I-II, q. 24, a. 4.

${ }^{29}$ STh I-II, q. 56, a. 4.

${ }^{30}$ STh I-II, q. 59, a. 5. Thomas's insistence on this point is not merely based on presuppositions about morality; it also reflects his understanding of the underlying metaphysical biology of the human person, including the relationship between body and soul, intellect and appetite. Anton Pegis, in his classic essay "St. Thomas and the Unity of Man," highlights this connection in Thomas's thought: "If all the powers of man are rooted in the soul; if, furthermore, one and the same intellectual soul has within its nature bot intellectual and sensible powers, this fact must mean, not that the soul has more powers than the intellect, but that the human intellect is not fully an intellect without sensible powers," in Progress in Philosophy: Philosophical Studies in Honor of Rev. Doctor Charles A. Hart, ed. James A. McWilliams, S.J. (Milwaukee, WI: Bruce Publishing Co., 1955), 169.

${ }^{31}$ White, "The Passions of the Soul," 111.

${ }^{32}$ STh I-II, q. 69, a. 2: “Cum enim aliquis incipit proficere in actibus virtutum et donorum, potest sperari de eo quod perveniet et ad perfectionem viae, et ad perfectionem patriae" (emphasis mine).
} 
broadest possible range of human affectivity. In order to gain an understanding of how differing states of humanity are determinate for which passions will be present in the human person, one must look outside the treatise on the passions.

\section{Humanity Created: Adam, the State of Innocence, and the Fall from Grace}

Given Thomas's analysis of the passions in the Prima Secundae, one might be inclined to suppose that he is describing a "default" mode of human existence, i.e. humanity as it existed from the moment of its creation. Yet, to find Thomas's explicit views on the primitive state, one must turn to the treatise on man in the Prima Pars. ${ }^{33}$ There we find that Thomas's characterization of primitive humanity (Adam, the first man) diverges in significant respects from the humanity that is under analysis in the Second Part of the Summa. Thomas holds that Adam's humanity differed from ours in respect to mortality, ${ }^{34}$ bodily passibility, ${ }^{35}$ affectivity, ${ }^{36}$ virtue,${ }^{37}$ knowledge ${ }^{38}$ and external environment. ${ }^{39}$ Attention to these differences will illuminate important insights of Thomas's theological anthropology, and, as we shall see later when compared to the humanity of Christ, they also reveal insights of his Christology and moral theology.

Following the biblical narrative in Genesis 1-3, Thomas maintains that Adam would not have died had he not eaten from the tree of the knowledge of good and evil. But this does not mean that Adam was created as "naturally" immortal. Rather, Thomas explains, the first man possessed a material body just like ours, and matter is prone to decay. Adam's immortality, then,

${ }^{33}$ STh I, qq. 75-102.

${ }^{34}$ STh I, q. 97 , a. 1.

${ }^{35}$ STh I, q. 97, a. 2.

${ }^{36}$ STh I, q. 95 , a. 2.

${ }^{37}$ STh I, q. 95 , a. 3.

${ }^{38}$ STh I, q. 94 , a. 3.

${ }^{39}$ STh I, q. 95, a. 2. 
originated not in some intrinsic principle of his humanity, but in the direct power of God. "For man's body," he explains, "was indissoluble not by reason of any intrinsic vigor of immortality, but by reason of a supernatural force given by God to the soul, whereby it was enabled to preserve the body from all corruption so long as it remained itself subject to God. ${ }^{40}$ Similarly, Adam's body was impassible and thus immune from injury or corruption. This was the case partly due to God's active preservation, but also due to Adam's ability to avoid harm through the use of reason. ${ }^{41}$ Thus, while Adam's body had the same physical nature as ours, it was nevertheless incorruptible and impassible while he dwelled in paradise and would have remained so had he not sinned.

Another important difference is that Adam's external environment did not necessitate the same passions that exist in postlapsarian humanity. Thomas bases this on his reading of Romans 5:12 ("By sin death came into the world"), such that the Fall not only effected an internal disordering of human desire, but also an alteration of the external world itself. God's preservation of Adam - the source of his incorruptibility and impassibility - was removed, and he now faced physical dangers that had been unknown before. Before the Fall, however, he did not possess the passions that pertained to present or immanent evil, or to a good not possessed. Thus, while he potentially possessed the full range of human passions, the movements of his sensitive appetite (and, thereby, the range of passions actually expressed) were different from

\footnotetext{
${ }^{40}$ STh I, q. 97, a. 1: "Non enim corpus eius erat indissolubile per aliquem immortalitatis vigorem in eo existentem; sed inerat animae vis quaedam supernaturaliter divinitus data, per quam poterat corpus ab omni corruptione praeservare, quandiu ipsa Deo subiecta mansisset." In this article, Thomas describes three different types of incorruptibility. The first is that of matter that is "in potentiality to one form only," such as the heavenly bodies. The second is the "incorruptibility of glory," which stems from the soul's (as the form of the body) beatification, as the soul's incorruptibility "redounds" to the body itself (Thomas cites an obscure passage from Augustine to support this claim). As Thomas will describe later in the Summa, this bodily incorruptibility that stems from the redounding of glory is found in Christ's post-resurrection body (STh III, q. 54, a. 2 ad 2, inter alia). The third kind is that brought about by efficient cause, and this is the relevant type of incorruptibility that describes Adam's body. See also $S T h$ I, a. 97, a. 4 on the tree of life as the cause of Adam's immortality.

${ }^{41}$ STh I-II, q. 97, a. 2 ad 4: "[C]orpus hominis in statu innocentiae poterat praeservari ne pateretur laesionem ab aliquo duro, partim quidem per propriam rationem, per quam poterat nociva vitare; partim etiam per divinam providentiam, quae sic ipsum tuebatur, ut nihil ei occurreret ex improviso, a quo laederetur.
} 
ours as necessitated by a different environment - namely, an environment devoid of sin and death. $^{42}$

As a result of Adam existing in paradise (as opposed to the postlapsarian world), the list of passions belonging to him is truncated. This does not imply that he was anything less than fully human; it simply reflects the fact that there were things absent in Adam's surroundings that would have activated certain passions. Thomas writes,

And since in the primitive state, evil was neither present nor imminent, nor was any good wanting which a good-will could desire to have then, as Augustine says (De Civ. Dei xiv, 10), therefore Adam had no passion with evil as its object; such as fear, sorrow, and the like; neither had he passions in respect of good not possessed, but to be possessed then, as burning concupiscence. ${ }^{43}$

Adam did, of course, possess the passions of joy, love, desire, and hope, as these pertain to either a future or present good. Nevertheless, Thomas offers the qualification that these passions existed "otherwise" than they exist in present humanity. This is because in present humanity (as a result of the punishment of original sin) the passions are not entirely subject to reason. "But in the state of innocence," he explains, "the inferior appetite was wholly subject to reason: so that in that state the passions of the soul existed only as consequent upon the judgment of reason." ${ }^{44}$ Thus, Adam exhibited four of the eleven passions (or, two of the four principal passions), and these existed in a state of perfect harmony with his reason.

\footnotetext{
${ }^{42}$ I use the word "potentially" for lack of a better term. Thomas reserves the word "habitually" for the virtues (not the passions themselves), since virtues are habits, whereas passions are movements of the sensitive appetite. The point is that, had pre-fallen Adam been placed in an environment like ours, this would have "activated" the passions that had previously been hidden (See $S T h$ I, q. 95, a. 3 ad 2), and we can infer that Thomas believes this to be what did, in fact, happen when Adam was removed from the state of original justice.

${ }^{43}$ STh I, q. 95, a. 2: "Et quia in primo statu nullum malum aderat nec imminebat; nec aliquod bonum aberat, quod cuperet bona voluntas pro tempore illo habendum, ut patet per Augustinum XIV de Civ. Dei, omnes illae passiones quae respiciunt malum, in Adam non erant ut timor et dolor et huiusmodi; similiter nec illae passiones quae respiciunt bonum non habitum et nunc habendum, ut cupiditas aestuans."

${ }^{44}$ Ibid.: "In statu vero innocentiae inferior appetitus erat rationi totaliter subiectus, unde non erant in eo passiones animae, nisi ex rationis iudicio consequentes."
} 
Furthermore, given that Adam possessed some passions and that those passions belong to the sensitive appetite, combined with the fact that he was created in the state of grace, ${ }^{45}$ Thomas concludes that Adam possessed all of the virtues. ${ }^{46}$ The only qualification he offers is that certain virtues involve a kind of imperfection that is incompatible with the primitive state, in which case Adam did not possess such virtues. These would include virtues such as penance and mercy, which imply the activation of passions such as sorrow, which, as we have seen, did not belong to Adam, since they were incompatible with the perfection of paradise. Yet, there are two senses in which it can be affirmed that Adam possessed the fullness of the virtues. The first is simply to acknowledge, as Thomas does, that Adam possessed all virtues at least in the form of habit, if not in act. ${ }^{47}$ In other words, if his environment had called for actions stemming from such virtues, Adam would have acted upon them. The other sense in which it is correct to attribute all virtues to Adam is to affirm that he possessed, both in habit and in act, all of the cardinal virtues (justice, prudence, temperance, and fortitude) as well as the theological virtues (faith, hope, and charity). Some of these virtues do not imply any sort of imperfection (e.g. charity and justice), while some do imply an imperfection, yet in a mode that is compatible with the primitive state (e.g. faith and hope). Thomas writes, "For the perfection of that state did not extend to the vision of the Divine Essence, and the possession of God with the enjoyment of final beatitude. Hence faith and hope could exist in the primitive state, both as to habit and as to act."48 Adam even

\footnotetext{
${ }^{45}$ STh I, q. 95, a. 1.

${ }^{46}$ STh I, q. 95, a. 3: "[H]

${ }^{47}$ Ibid.: "Unde huiusmodi virtutes erant in primo homine secundum habitum, sed non secundum actum."

${ }^{48}$ Ibid.: "Perfectio enim primi status non se extendebat ad hoc, ut videret Deum per essentiam, et ut haberet eum cum fruitione finalis beatitudinis, unde fides et spes esse poterant in primo statu, et quantum ad habitum et quantum ad actum."
} 
possessed the moral virtues, since these moderate not only "negative" passions such as sorrow or fear (which were absent in Adam), but also "positive" passions such as joy and hope. ${ }^{49}$

Humanity's fall from grace through Adam's sin constituted a monumental change in the functions human affectivity. In the primitive state, through a supernatural endowment of grace, the body was subject to the soul, and the lower powers of the soul (i.e. passions) were subject to the higher powers (i.e. reason). ${ }^{50}$ This supernatural endowment was lost, however, with the first sin. Thomas cites Augustine's narration of this event: "Hence Augustine says (De Civ. Dei xiii, 13) that, as soon as they disobeyed the Divine command, and forfeited Divine grace, they were ashamed of their nakedness, for they felt the impulse of disobedience in the flesh, as though it were a punishment corresponding to their own disobedience." ${ }^{, 51}$ Thus, the disordering of the passions in relation to reason falls within the scope of divine providence, since it reflects the just sentence of God that grace was removed. Thomas goes on to explain, "Hence if the loss of grace dissolved the obedience of the flesh to the soul, we may gather that the inferior powers were subjected to the soul through grace existing therein." ${ }^{, 52}$ Yet grace was lost, and thus the harmony between flesh and soul was ruptured.

According to Thomas, a consequence of the Fall is that the fomes peccati ("spark" of sin) has been inscribed in the human condition. Thus, no matter how much progress an individual

\footnotetext{
${ }^{49}$ STh I, q. 95, a. 3 ad 2: "Unde poterat esse in primo statu actus temperantiae, secundum quod est moderativa delectationum; et similiter fortitudo, secundum quod est moderativa audaciae sive spei; non autem secundum quod moderantur tristitiam et timorem."

${ }^{50}$ It is worth noting that Thomas's position on grace in the primitive state does not necessarily reflect a scholastic consensus. For example, Peter Lombard's own position on the subject was unclear, and Thomas acknowledges the existence of conflicting opinions in STh I, q. 95, a. 1 ad 4. See also De Malo, q. 5, a. 1 ad 13: "quia cum originalis iustitia primordialiter consistat in subiectione humanae mentis ad Deum, quae firma esse non potest nisi per gratiam, iustitia originalis sine gratia esse non potuit. Et ideo habenti originalem iustitiam debebatur visio divina." Citations from De Malo are taken from The De Malo of Thomas Aquinas (Latin and English), trans. Richard Regan (Oxford: Oxford University Press, 2001).

${ }^{51}$ STh I, q. 95, a. 1: "Unde Augustinus dicit, XIII de Civ. Dei, quod posteaquam praecepti facta transgressio est, confestim, gratia deserente divina, de corporum suorum nuditate confusi sunt, senserunt enim motum inobedientis carnis suae, tanquam reciprocam poenam inobedientiae suae."

52 Ibid.: "Ex quo datur intelligi, si deserente gratia soluta est obedientia carnis ad animam, quod per gratiam in anima existentem inferiora ei subdebantur." See also De Malo, q. 5, a. 1.
} 
makes in achieving virtue (even to the point of achieving general stability between one's reason and one's passions), the "spark" of sin is always present as a threat to the operation of reason. The pervasive influence of this doctrine in Thomas's theology can be seen in his frequent use of Rom. 7:23, "I see another law in my members, fighting against the law of my mind, and captivating me in the law of $\sin [$ lege peccati]." He equates this law with concupiscence itself: "Now the law that is in the members is concupiscence, of which [Paul] had been speaking previously. Since then concupiscence is a passion, it seems that a passion draws reason counter to its knowledge." ${ }^{53}$ Yet, for Thomas, "[S]in does not belong to human nature, whereof God is the cause; but rather has been sown in it against its nature by the devil., ${ }^{, 54}$ God has created human beings with certain passions, but concupiscence is not one of them. ${ }^{55}$

In his commentary on St. Paul's Epistle to the Romans, Thomas elaborates on the Pauline conception of the fomes peccati as it relates the varying stages of humanity. "This law," he writes, "is found in the sensitive appetite as in its source, but it is found spread over all the members which play a role for concupiscent desire in sinning." ${ }^{, 56} \mathrm{He}$ observes that this law has two effects in the person: it resists reason, and it makes the person a slave (hominem in servitutem $).{ }^{57}$ But this second effect does not obtain equally in all persons in whom it resides. For those who have received the healing that comes from grace, the fomes of sin, while still present, does not rule in the person to the extent that it compels consent and action. In Thomas's terms,

\footnotetext{
${ }^{53}$ STh I-II, q. 77, a. 2 sc: "Lex autem quae est in membris, est concupiscentia, de qua supra locutus fuerat. Cum igitur concupiscentia sit passio quaedam, videtur quod passio trahat rationem etiam contra hoc quod scit."

${ }^{54}$ STh III, q. 5, a. 1: “[P] eccatum non pertinet ad humanam naturam, cuius Deus est causa; sed magis est contra naturam per seminationem Diaboli introductum."

${ }^{55}$ Concupiscence here refers to the disordered concupiscence resulting from original sin, not to the passion concupiscentia. Thomas clarifies this distinction in STh I-II, q. 82, a. 3 ad 1.

${ }^{56}$ Ad Rom. 7:23, lect. 4 (§ 588): "Haec autem lex originaliter quidem consistit in appetite sensitivo, sed diffusive invenitur in omnibus membris, quae deserviunt concupiscentiae ad pecandum." Citations of Thomas's Romans commentary are from Thomas Aquinas, Commentary on the Letter of Saint Paul to the Romans (Latin and English), trans. F. R. Larcher, O.P., ed. J. Mortensen and E. Alarcón (Lander, WY: The Aquinas Institute for the Study of Sacred Doctrine, 2012).

${ }^{57}$ Ibid.
} 
"[T]he law of sin makes man captive in two ways: the sinner it makes captive through consent and action; the man in grace through the movement of concupiscent desire." ${ }^{, 58}$ For Thomas, to interpret the fomes of sin as a law depends not only on a conception of human nature per se, but on an account of the precise human state that is under consideration. Adam represents one such state (i.e. original justice); all those living after Adam constitute present humanity, yet within this category there exist those who are in a state of grace - the fomes applies to all, but in different ways. Furthermore, Thomas asserts that Jesus is the only human being who ever lived who did not possess the fomes of sin; the fact he did not inherit original sin meant that he was not subject to this "law." In order to understand the significance of this claim, we must turn to a more detailed consideration of Christ's humanity.

\section{The Humanity of Christ: The Passions of the Second Adam}

At the very beginning of his treatise on the Incarnation, Thomas offers numerous reasons that the second person of the Trinity, the divine Word, became incarnate. In addition to the general "fittingness" (convenientia) of the Incarnation as an expression of God's goodness communicating itself to others, ${ }^{60}$ Thomas provides several considerations of what the Incarnation accomplished on humanity's behalf. The first set of considerations falls under the heading of “our furtherance in good." ${ }^{61}$ He demonstrates how the Incarnation stirs up and increases our faith, hope, and charity, as well as provides a real, human example of right living (rectam operationem) and a means of participating in God's own divinity, "which is the true bliss of man

\footnotetext{
${ }^{58}$ Ibid.: "Lex autem peccati captivat hominem dupliciter. Uno modo hominem peccatorem per consensum et operationem; alio modo hominem sub gratia constitutum quantum ad concupiscentiae motum."

${ }^{59}$ STh III, q. 15 , a. 2.

${ }^{60}$ STh III, q. 1, a. 1: "Unde ad rationem summi boni pertinet quod summo modo se creaturae communicet. Quod quidem maxime fit per hoc quod naturam creatam sic sibi coniungit ut una persona fiat ex tribus, verbo, anima et carne, sicut dicit Augustinus, XIII de Trin. Unde manifestum est quod conveniens fuit Deum incarnari."

${ }^{61}$ STh III, q. 1, a. 2.
} 
and end of human life; and this is bestowed upon us by Christ's humanity." ${ }^{\circ 2}$ Moreover, the Incarnation was useful (utile) for our withdrawal from evil, not least in accomplishing satisfaction for human sin and providing the healing effects of grace. It is in this respect that St. Paul refers to Christ as a second Adam, "For as in Adam all die, so also in Christ shall all be made alive" (1 Cor. 15:22, RSV).

Thomas's is a single-subject Christology, in which the Word assumes human nature in the one person of Jesus Christ, the God-man. Thomas's mode of understanding this union is that Christ's humanity is the personal, conjoined, animate instrument of his divinity. ${ }^{63}$ This humanity is not merely human "flesh," but includes a fully human body and soul, including the lower, appetitive powers of the soul. In the Summa contra Gentiles, he provides the analogy of a hand as an instrument of the soul; when one uses a tool, such as an axe, this is not a direct instrument of the soul, but rather an external and common instrument. The hand, as instrument, is united to the soul in a way that the axe is not. Thomas explains that Christ's humanity (in its entirety) was an instrument in a similar way:

But the human nature in Christ is assumed with the result that instrumentally He performs the things which are the proper operation of God alone: to wash away sins, for example, to enlighten minds by grace, to lead into the perfection of eternal life. The human nature of Christ, then, is compared to God as a proper and conjoined instrument is compared, as the hand is compared to the soul. ${ }^{64}$

\footnotetext{
${ }^{62}$ Ibid.: "quantum ad plenam participationem divinitatis, quae vere est hominis beatitudo, et finis humanae vitae. Et hoc collatum est nobis per Christi humanitatem, dicit enim Augustinus, in quodam sermone de Nativ. domini, factus est Deus homo, ut homo fieret Deus."

${ }^{63}$ See $S T h$ III, q. 2, a. 6.

${ }^{64} \mathrm{ScG}$ IV , c. 41: "Sed humana natura in Christo assumpta est ut instrumentaliter operetur ea quae sunt operationes propriae solius Dei, sicut est mundare peccata, illuminare mentes per gratiam, et introducere in perfectionem vitae aeternae. Comparatur igitur humana natura Christi ad Deum sicut instrumentum proprium et coniunctum, ut manus ad animam." Citations of the $S c G$ are from Thomas Aquinas, Summa Contra Gentiles, Book IV: Salvation, trans. Charles J. O'Neil (Notre Dame, IN: University of Notre Dame Press, 1975). The Latin text is from the Leonine edition, which can be found at: http://www.corpusthomisticum.org.
} 
Thus, Christ, as man, is able to work and perform those things that belong exclusively to the power of God; the Word, as God, is acting through the instrument of his humanity, which he assumed in the Incarnation.

In order to make sense of such claims as "Christ assumed human nature," or "Christ's humanity was the instrument of his divinity," one must have some prior account of what constitutes humanity in and of itself. Not only that, but one must understand which condition or state of humanity is reflected in that which Christ assumed. Marilyn McCord Adams succinctly frames the question thusly:

What sort of human nature did Christ assume? One like Adam's and Eve's before the fatal apple? One fallen and ungraced like murderous Cain's? A human nature such as ours, fallen but helped by grace? A human nature already glorified impassible, immortal, capable of walking through doors or ascending through uneven heavens? If each of these states is compatible with as well as accidental to human nature, Christ could be fully human in any one of them. ${ }^{65}$

Thomas is well aware that this question must be answered, and he devotes much space in the Tertia Pars and elsewhere to answering it. One of the ways he approaches this question is by considering the various "defects" that Christ assumed in human nature. These defects are particular features of humanity (considered within the full spectrum of its various states) that Christ assumed voluntarily. According to Thomas, Christ assumed these defects for three reasons: 1) soteriological: that he might satisfy for our $\sin , 2)$ doctrinal: that he might prove the truth of his human nature, and 3) moral: that he might become an example of virtue to us. ${ }^{66}$ These reasons also serve as the criteria for determining which specific defects Christ did or did not assume.

\footnotetext{
${ }^{65}$ Marilyn McCord Adams, What Sort of Human Nature?: Medieval Philosophy and the Systematics of Christology (Milwaukee, WI: Marquette University Press, 1999), 9.

${ }^{66}$ Thomas provides these three reasons in both STh III, q. 14, a. 1 and III, q. 15, a. 1.
} 
Regarding defects of the body, Thomas affirms that Christ assumed a human body that reflects humanity's current state - that is, a body that is passible and mortal. His argument for this is summed up in the sed contra of STh III, q. 14, a. 2: "The Apostle says (Rom. 8:3) that God sent His own Son in the likeness of sinful flesh. Now it is a condition of sinful flesh to be under the necessity of dying, and suffering other like passions. Therefore the necessity of suffering these defects was in Christ's flesh." ${ }^{67}$ Thus, these defects were "necessary" in the sense that Christ had to take them on in order to fulfill the purposes of the Incarnation, i.e. to procure the salvation of wayward humanity. They were voluntary, however, in the sense that Christ assumed them of his own free will. Thus, Christ's bodily humanity was resolutely like our own; it was subject to harm, decay, and death, as these realities were the result of Adam's sin. Unlike Adam's body, it was not preserved in immortality by a divine dispensation, which suggests that, had Christ not died by means of crucifixion, his body would nevertheless have been prone to death just like any other human body. Christ did not "contract" these defects simply in virtue of his human generation, however, since this only occurs through the inheritance of original $\sin ^{68}$ Rather, they were voluntarily assumed, because, in the words of John Damascene, "What is unassumable is incurable." ${ }^{\prime 69}$ As Thomas explains, "[S]ince Christ healed the passibility and corruptibility of our body by assuming it, He consequently healed all other defects." ${ }^{, 70}$ Thus, Christ did not inherit original sin, but he inherited certain bodily defects that were the result of Adam's sin, in order that he might heal them.

\footnotetext{
67 "Sed contra est quod apostolus dicit, Rom. VIII, misit Deus filium suum in similitudinem carnis peccati. Sed conditio carnis peccati est quod habeat necessitatem moriendi, et sustinendi alias huiusmodi passiones. Ergo talis necessitas sustinendi hos defectus fuit in carne Christi."

${ }^{68}$ STh III, q. 14, a. 3.

${ }^{69}$ Cited in STh III, q. 14, a. 4 obj. 1: "[Q]uod est inassumptibile, est incurabile."

${ }^{70}$ STh III, q. 14, a. 4 ad 1: "Et ideo, dum Christus curavit passibilitatem et corruptibilitatem corporis nostri per hoc quod eam assumpsit, ex consequenti omnes alios defectus curavit."
} 
Regarding defects of the soul, Thomas's answer is a bit more complicated. One major source of this complication is foreshadowed in his discussion of the Christ's bodily defects. In a reply to an objection, Thomas explains that, while Christ enjoyed the fullness of the beatific vision from the moment of his conception, ${ }^{71}$ the natural relationship between body and soul "in Christ was subject to the will of His Godhead, and thereby it came to pass that the beatitude remained in the soul, and did not flow into the body; but the flesh suffered what belongs to a passible nature." ${ }^{, 72}$ Thus, Christ's beatific vision, which under normal circumstances would redound throughout the body and render it impassible, was partitioned off in the upper powers of his soul during his life prior to the resurrection. ${ }^{73}$ This position of Thomas's becomes partly determinative of which passions he ascribes to Christ's soul.

In addition to bodily defects, Christ likewise assumed defects of soul, including the passions. ${ }^{74}$ Thomas had wrestled with the subject of Christ's passions in his earlier works, and the closest he came to a systematic treatment appears in De Vertiate. ${ }^{75}$ Unlike in the Summa, Thomas includes his analysis of Christ's passions within his general analysis of the passions, under the heading of a single Question. As Mark Jordan observes, Thomas's discussion of the

\footnotetext{
${ }^{71}$ Thomas establishes this claim earlier in STh III, q. 9, a. 2.

${ }^{72}$ STh III, q. 14, a. 1 ad 2: "[H]aec naturalis habitudo in Christo subiacebat voluntati divinitatis ipsius, ex qua factum est ut beatitudo remaneret in anima et non derivaretur ad corpus, sed caro pateretur quae conveniunt naturae passibili."

${ }^{73}$ Thomas's view on this matter was not unique for his time. Many scholastics (including Thomas's teacher, Albert) maintained that Christ enjoyed the beatific vision throughout his earthly life. Contrary to modern expectations, what was more controversial in Thomas's own day (and even in the patristic period) was the view that Christ had a passible human soul. Following a trajectory initiated by Hilary of Portiers, the patristic and medieval theologians were concerned about the implications of the view that Christ possessed animal passions. Kevin Madigan, in his monograph, The Passions of Christ in High-Medieval Thought: An Essay on Christological Development (Oxford: Oxford University Press, 2007) offers a useful survey of medieval thought on this topic, but its polemical aims render it less helpful than it might be otherwise. It also suffers from failing to engage with Gondreau's important work (see below), as Madigan himself concedes in the introduction. On Christ's beatific vision, see also Paul Gondreau, The Passions of Christ's Soul, 441-52.

${ }^{74}$ As Gondreau notes, "Because most studies on human affectivity in the thought of Thomas Aquinas have ignored the role of passion in Christ's humanity, the notion of passion as defect has all but eluded the attention of Thomist scholars. Yet, the concept of defect represents a whole other side to passibility that is no less fundamental to the issue, and without it one fails to grasp the essence of Thomas' take on Christ's human affectivity, as it demarcates the proper context in which one examines Christ's passions," The Passions of Christ's Soul, 220.

${ }^{75}$ De Veritate, q. 26, aa. 8-10.
} 
passions in De Veritate is unique in that it "tries to combine the Christological and virtuecentered occasions for discussing [the passions]. ${ }^{, 76}$ The structure of the articles follows a progression of discussion of the passions in general, to whether passions were in Christ's soul, and finally, to a discussion of Christ as "wayfarer and comprehensor" (viator et comprehensor). Yet another dissimilarity from the Summa is that Thomas refrains from enumerating specific passions to Christ, but rather focuses his analysis on the compatibility of the passions with his human and divine nature. ${ }^{77}$

Thomas's treatment of Christ's passions in the Summa reflects his most mature and systematic treatment of the topic. He begins his analysis by stating that Christ's passions were in him "otherwise than us" in three ways: 1) regarding their object: they did not tend toward what is unlawful, 2) regarding their principle: they did not forestall the judgment of reason, and 3) regarding their effect: they remained in the sensitive appetite. ${ }^{78}$ Regarding the latter distinction, Thomas deploys the term "propassion" (propassio, a term borrowed from Jerome) to distinguish that which remains in the sensitive appetite from "perfect passions" (passio perfecta), which dominate reason; these terms thus mark the progression of a passion's movement in the soul. Thomas's next move is to establish that Christ did, in fact experience sensible pain, since "for true bodily pain are required bodily hurt and the sense of hurt." ${ }^{, 79}$ This is important to establish from the outset, since, for Thomas, touch is the foundation of all the senses ${ }^{80}$ and is thus foundational in establishing Christ's human affectivity. ${ }^{81}$

\footnotetext{
${ }^{76}$ Jordan, “Aquinas's Construction,” 85.

${ }^{77}$ According to Jean-Pierre Torrell, Thomas wrote De Veritate sometime around 1256-1259, placing it roughly thirteen to sixteen years before the Tertia Pars. Jean-Pierre Torrell, Saint Thomas Aquinas, Vol. 1: The Person and His Work, trans. Robert Royal (Washington, DC: Catholic University of America Press, 1996), 328.

${ }^{78}$ STh III, q. 15, a. 4. Recall Thomas's similar phrasing regarding Adam's passions in STh I, q. 95, a. 2.

${ }^{79}$ STh III, q. 15, a. 5.

${ }^{80}$ See $S T h$ I, q. 91 , a. 3.

${ }^{81}$ Gondreau notes, "[T] he physical action or appetitive movement of a passion always entails a bodily modification, as the passions are exercised by means of a bodily organ," The Passions of Christ's Soul, 221.
} 
Thomas then proceeds, in a series of articles, to address specific passions in regard to Christ. He affirms that Christ experienced sorrow, fear, wonder, and anger. This particular list of passions may seem peculiar at first. Thomas does not claim that these were the only passions in Christ, but neither does he explicitly state why only these are addressed in Question 15. Moreover, wonder (admiratio) is not included among the "canonical" passions classified in the treatise in the Prima Secundae; it is a species of fear. ${ }^{82} \mathrm{He}$ grants that Christ possessed the congenial passions (love, desire, joy, and hope) but does not offer an analysis of them, and he does not address daring or despair in Christ at all. This neglect may simply reflect Thomas's fidelity to the biblical witness to Christ's life on earth as attested by the four Gospels. Paul Gondreau offers the observation that the selection of and the order in which Thomas treats Christ's passions “observes a strategic plan purposefully designed to offer the most convincing rejoinder to those who wish to dispute the reality of such affective occurrences in Jesus' life," especially those influenced by Hilary of Portiers or by a general Stoic disdain for the passions. ${ }^{83}$ Thomas is concerned to demonstrate the fullness of Christ's humanity, and the concerns of his interlocutors dictate the priority in his treatment of Christ's passions. ${ }^{84}$

Concerning Christ's virtues, Thomas affirms, "since the grace of Christ was most perfect, there flowed from it, in consequence, the virtues which perfect the several powers of the soul for all the soul's acts; and thus Christ had all the virtues." ${ }^{15}$ Yet, he qualifies this affirmation by

\footnotetext{
${ }^{82}$ STh I-II, q. 41, a. 4 ad 4: "Ad quartum dicendum quod non quaelibet admiratio et stupor sunt species timoris, sed admiratio quae est de magno malo, et stupor qui est de malo insolito." On the peculiarity of Thomas's treatment of admiration in Christ, see Gondreau, The Passions of Christ's Soul, 414-27.

${ }^{83}$ Gondreau, The Passions of Christ's Soul, 453.

${ }^{84}$ For a thorough exposition of Thomas's christological and anthropological sources in developing his account of Christ's passions, see Chs. 1 and 2 in Ibid.

${ }^{85}$ STh III, q. 7, a. 2: "Unde, cum gratia Christi fuerit perfectissima, consequens est quod ex ipsa processerint virtutes ad perficiendum singulas potentias animae, quantum ad omnes animae actus. Et ita Christus habuit omnes virtutes."
} 
stating that Christ did not possess the theological virtues of faith or hope ${ }^{86}$ This reveals another implication of Thomas's position on Christ's beatific vision. While the beatific vision was prevented from affecting the passibility of Christ's body during his life, it was nevertheless manifest in the upper powers of his soul, and, therefore, since he saw God in very essence, Christ had no need for these theological virtues. ${ }^{87}$ While Thomas's reasoning may strike some contemporary readers as counterintuitive, it can at least be recognized that Thomas's logic follows what St. Paul says about these virtues in his epistle to the Corinthians, "For now we see in a mirror dimly, but then face to face. Now I know in part; then I shall understand fully, even as I have been fully understood. So faith, hope, love abide, these three; but the greatest of these is love" (1 Cor. 13:12-13, RSV). Since Christ's human soul, through its proximity to and union with the Word, saw God "face to face," as it were, he had already begun to model in some respects the experience of glorified humanity after the resurrection.

\section{Humanity Transformed: Christ as Viator et Comprehensor}

It is in this qualification of "in some respects" that we can begin to make sense of Thomas's claim that Christ is both viator et comprehensor ${ }^{88}$ In some respects, he resembles our humanity as viator; in other respects, he resembles our future state of humanity as comprehensor, for which we long. The crucial move, for Thomas, is to affirm that Christ voluntarily took on defects of humanity's present, postlapsarian state while at the same time avoiding the effects of original sin. This allowed his humanity - a very specific kind of humanity - to operate as the instrument

\footnotetext{
${ }^{86}$ STh III, q. 7, a. 3: "Et ideo, excluso quod res divina non sit visa, excluditur ratio fidei. Christus autem in primo instanti suae conceptionis plene vidit Deum per essentiam, ut infra patebit. Unde fides in eo esse non potuit," and STh III, q. 7, a. 4: "Christus autem a principio suae conceptionis plene habuit fruitionem divinam, ut infra dicetur." ${ }^{87}$ See STh III, q. 34, a. 1.

${ }^{88}$ STh III, q. 15 , a. 10.
} 
of divine power in procuring salvation for the human race. He assumed all of the passions, yet conquered the disordered fomes of sin by winning victory over sin itself.

While some readers may wish for a Christ that knew the experience of sin firsthand, Thomas is adamant that Christ's victory over sin is all the greater due to the fullness of his virtue. Yet, Thomas imagines such an objection, and he offers the following reply:

The spirit gives evidence of fortitude to some extent by resisting that concupiscence of the flesh which is opposed to it; yet a greater fortitude of spirit is shown, if by its strength the flesh is thoroughly overcome, so as to be incapable of lusting against the spirit. And hence this belonged to Christ, whose spirit reached the highest degree of fortitude. And although He suffered no internal assault on the part of the 'fomes' of sin, He sustained an external assault on the part of the world and the devil, and won the crown of victory by overcoming them. ${ }^{89}$

Thus, for Thomas, Christ's exemplarity is not accomplished by taking on all defects of our humanity (including sin) and then showing us how to "cope" with them or rise above them. Rather, Christ is exemplar in that he both shows us the final end toward which are striving and also provides, in himself, the means of making our salvation possible. ${ }^{90}$ In being both viator et comprehensor, he moves us onward in our present state of viator towards being comprehensor. ${ }^{91}$

The First Adam's perfection in virtue provided a kind of exemplarity, but it is only Christ who

\footnotetext{
${ }^{89}$ STh III, q. 15, a. 2 ad 3: "[F] ortitudo spiritus aliqualis ostenditur ex hoc quod resistit concupiscentiae carnis sibi contrariantis, sed maior fortitudo spiritus ostenditur si per eius virtutem totaliter comprimatur, ne contra spiritum concupiscere possit. Et ideo hoc competebat Christo, cuius spiritus summum gradum fortitudinis attigerat. Et licet non sustinuerit impugnationem interiorem ex parte fomitis, sustinuit tamen exteriorem impugnationem ex parte mundi et Diaboli, quos superando victoriae coronam promeruit."

${ }^{90}$ Jean-Pierre Torrell explores the important distinction between 'moral exemplarity' and 'ontological exemplarity' in Christ and Spirituality in St. Thomas Aquinas, trans. Bernhard Blankenhorn, O.P. (Washington, DC: Catholic University of America Press, 2011), 110-125. Similarly, Joseph Wawrykow argues that for Thomas, Jesus is the ultimate moral exemplar and that the notions of virtue and human flourishing are themselves shaped by conformity to Jesus and the reception of the Jesus' virtues and gifts in "Jesus in the Moral Theology of Thomas Aquinas," Journal of Medieval and Early Modern Studies, Vol. 42, No. 1 (Winter 2012): 13-33.

${ }^{91}$ Adams describes the connection between the Incarnation and our own beatitude: "For Aquinas [...], Christ as prototype and head pioneers human excellence - both natural and supernatural - by exemplifying it, to a large extent even during his earthly career. If union with God is the human end, Christ's human nature enjoys if from its beginning by virtue of the Incarnation," What Sort of Human Nature?, 52.
} 
shows us the fullness of humanity - including the full range of human passions - in its perfection. $^{92}$

Thus, Christ's pre-resurrection humanity serves as a kind of bridge between fallen humanity and humanity in the glorified state, yet it is not as if it were "a little bit of both"; Thomas wants to affirm that Christ exhibited the fullness of both. Christ took on all of humanity's passions, but in the process of this assumption, he healed the disordering that had been brought about through the sin of the First Adam. In his earlier work, De Veritate, Thomas writes,

"In Christ there was no mingling of joy and pain. For joy was in His higher reason viewed under the aspect of its being the principle of its own act, for it was in this way that it enjoyed the possession of God. Pain, however, was not in it except in so far as the injuring of the body touched it as the act of the body through the essence in which it was rooted, yet in such a way that the act of higher reason was in no wise hampered. Thus there was pure joy and likewise pure pain, and both in the highest degree." 93

Thomas maintained this position throughout his writing career, and it reflects a desire to accommodate the fullness of Christ's humanity and divinity. Equally important, however, is Thomas's desire to put Christ forward as the icon of humanity perfected, the fullness of virtue and holiness. In doing so, he also maps out the overarching telos of human affectivity, as it works in harmony with reason and ultimately finds its fulfillment in the impassibility that comes from resting in God in the beatific vision.

\footnotetext{
92 As Gondreau explains, “Aquinas secures as much inspiration from the affective occurrences surrounding Jesus' own life in the development of his teaching on the integral role of passion in the exercise of virtue as he takes from Aristotle's writings (though, of course, Aristotle has considerably more to say on the subject). That the sinless and supremely virtuous Christ should himself be subject to movements of passion makes therefore a decided impact on Aquinas, a fact that should not be abstracted from the Dominican's conviction that virtue (or holiness) and passion are not inherent adversaries, or from Thomas' consequential remark that 'the moral virtues... cannot be without the passions.' In short, for St. Thomas (as for Augustine), Christ, in his human passions, fully discloses the truth of human affectivity," The Passions of Christ's Soul, 320.

${ }^{93} \mathrm{De}$ Ver, q. 26, a. 10 ad 6: "[I]n Christo nulla permixtio facta est gaudii et doloris. Nam gaudium fuit in superiori ratione ex illa parte qua est principium sui actus: sic enim Deo fruebatur; dolor vero non erat in ipsa nisi secundum quod laesio corporis attingebat eam ut actum corporis mediante essentia in qua radicatur, ita tamen quod actus rationis superioris nullatenus impediebatur: et sic erat et purum gaudium et purus dolor; et sic utrumque in summo."
} 
The telos of humanity affectivity, as it participates in the moral life and ultimately

conforms to the exemplarity of Christ's own affectivity, is most clearly drawn when situated within the context of our present humanity and bookended by the First and Second Adam. The final picture Thomas provides is represented in the following:

\begin{tabular}{|c|c|c|c|}
\hline & First Adam & $\begin{array}{c}\text { Present } \\
\text { Humanity }\end{array}$ & Christ \\
\hline \multirow[t]{11}{*}{ Passions: } & love & love & love \\
\hline & hatred & hatred & hatred \\
\hline & desire & desire & desire \\
\hline & aversion & aversion & aversion \\
\hline & joy & joy & joy \\
\hline & sadness & sadness & sadness \\
\hline & hope & hope & hope \\
\hline & despair & despair & despair* \\
\hline & daring & daring & daring* \\
\hline & fear & fear & fear \\
\hline & anger & anger & anger \\
\hline \multirow[t]{4}{*}{ Virtues: } & faith & (faith) & faith \\
\hline & hope & (hope) & hope \\
\hline & charity & (charity) & charity \\
\hline & $\begin{array}{c}\text { [cardinal } \\
\text { virtues] }\end{array}$ & $\begin{array}{c}\text { [cardinal } \\
\text { virtues] }\end{array}$ & $\begin{array}{c}\text { [cardinal } \\
\text { virtues] }\end{array}$ \\
\hline
\end{tabular}

Even in the Prima Pars, Thomas had already begun to gesture towards this trajectory. He writes, for example, "In paradise man would have been like an angel in his spirituality of mind, yet with an animal life in his body. After the resurrection man will be like an angel, spiritualized in soul and body." ${ }^{94}$ Elsewhere, Thomas explains that while Adam was not placed in heaven when he

\footnotetext{
${ }^{94}$ STh I, q. 98, a. 2 ad 1: "[H]omo in Paradiso fuisset sicut Angelus per spiritualem mentem, cum tamen haberet, vitam animalem quantum ad corpus. Sed post resurrectionem erit homo similis Angelo, spiritualis effectus et secundum animam et secundum corpus. Unde non est similis ratio."
} 
was created, he was destined to transfer there "in the state of his final beatitude." "95 Although Thomas does not state it here, the model of this beatified soul and body is the glorified Christ himself; and, just as with the First Adam, Christ was not "created" in heaven, but was rather born as an Incarnate human being on earth. Yet, even during his life on earth, he was both viator et comprehensor.

What this reveals for us is our ultimate end in beatitude, yet this revelation also enhances our self-understanding as wayfarers. Christ's own passions are a model for us, and his humanity to which they belong enables us to conform to his likeness. ${ }^{96}$ As Servais Pinckaers writes, “Aquinas's particular interest in the emotions comes from their contribution to moral action and to human progress in one's journey toward God; it relates to the fact that sensation provides humans with a primary image and a basic vocabulary in order to express spiritual realities." ${ }^{97}$ For Thomas, Christ's beatific vision - limited to the upper powers of the soul - ensured the fullness of virtue and right ordering of the passions; it is an absolute given for him that Christ enjoyed the beatific vision from the moment of his conception. Whenever the issue arises in discussion, if Thomas ever feels the need to defend anything about his position, it is the fact that this beatific vision was limited to the upper powers of the soul (i.e. not the fact that Christ had the beatific vision). By virtue of its union with the Word, Christ's humanity (as personal, animate, conjoined instrument) possessed the fullness of virtue, such that the fomes of sin were excluded and his passions remained "pro-passions." In other words, what Thomas believes to be potentially counterintuitive about his own claim (and thereby in need of an explanation) is why the effects of

\footnotetext{
95 STh I, q. 102, a. 2 ad 1: “[N]on est positus a principio in caelo Empyreo; sed illuc transferendus erat in statu finalis beatitudinis." See also STh I, q. 102, a. 4.

${ }^{96}$ Reinhard Hütter writes, "The acts of the sense appetite are to support and intensify the acts of reason such that the embodied intellect advances ever more efficaciously on the road toward the true and the good; the homo viator is ever to proceed in order to achieve his or her twofold final end. And because sanctifying grace (by way of the infused theological and moral virtues) reaches all the way down to heal and re-order the passions and allow them to contribute even more fully to the perfection of the moral act," in "Body Politics," 99.

${ }^{97}$ Pinckaers, "Reappropriating Aquinas's Account," 277.
} 
Christ's beatific vision did not redound all the way to his body. And the reason to defend this particular claim is to allow room for the reality of Christ's human passions. Moreover, Thomas's logic points us to the reality that it is the glorified Christ who is the template for human existence - his glorified soul and body together provide the icon of the true comprehensor. ${ }^{98}$

\section{Conclusion}

One can imagine a reader of Thomas objecting that the Angelic Doctor is simply caught between the tension of wanting to claim, on the one hand, that Christ had to be sinless in order to procure our salvation and, on the other, that Christ offers a truly human example of virtue and holiness. On this reading, he errs on the side of former at the expense of latter. But when Thomas's full account of the passions is taken into consideration, including the narrative of humanity's changing conditions (during creation, fall, and redemption), we find that Christ is the only human example we have of someone who faced the same realities that we face and yet possessed the fullness of virtue. Adam possessed the fullness of virtue, but he did confront the realities of a fallen world; our present humanity exists under the "law of sin" (the fomes peccati) and, additionally, exists in a world tainted by mortality. Christ's humanity reaches even beyond Adam's by assuming our defects, thus, he is the most perfect human example of virtue as well as the means of achieving our final beatitude.

In some ways, the objection that Christ's humanity was sufficiently different from our own as to preclude him from being a true exemplar reveals more about one's assumptions

\footnotetext{
${ }^{98}$ Thomas's position on this matter remains controversial, even among Thomists. Even very fine readers of Thomas, such Torrell, Gondreau, and Thomas Weinandy take issue with Thomas on this point. I do not have the space to reproduce their arguments adequately (let alone engage them in a meaningful way), but I only hope that I have gestured toward another way we might be motivated to follow Thomas on this issue. For a careful and systematic response to the concerns of Thomas's detractors that argues on metaphysical grounds, see Thomas Joseph White, "The Voluntary Action of the Earthly Christ and the Necessity of the Beatific Vision," The Thomist 69 (2005): 497534.
} 
regarding the nature of virtue and morality than about one's Christological assumptions. Moreover, if one finds Thomas's account of Christ's human achievements to be problematic, then Adam's human achievements will be equally problematic. Both Adam and Christ had passions that existed in perfect harmony with reason (albeit for different reasons); both had the fullness of virtue (albeit in different senses), and the actions of both are considered more meritorious than our own. ${ }^{99}$ Thus, if one finds Thomas's account of Christ's exemplarity to be problematic without considering what Thomas also says about Adam's humanity, then perhaps the real concern is about the nature of virtue itself. But if this is the problem, then it is the very problem I hoped to remedy in this essay. Thomas's theological anthropology and moral theology are not detached from what has been revealed in Christ. As I have endeavored to demonstrate, Thomas's understanding of human affectivity finds it fulfillment in his analysis of Christ's affectivity. If we wish to comprehend the fullness of Thomas's account of the passions, we cannot afford to neglect what was for him the paradigm of restored humanity, namely, Christ himself.

\footnotetext{
${ }^{99}$ See, for example, STh I, q. 95 , a. 4.
} 